\title{
THE JOKE CYCLE ISLAND OF CANNIBALS: STRUCTURE, FUNCTIONS, MESSAGES
}

\author{
Grigor Haralampiev Grigorov
}

\begin{abstract}
The author argues that the fundamental interdependence between structure and meaning in the joke can be outlined only if the joke cycle is chosen as a main research topic. As an example, the joke cycle Island of cannibals is analysed. The specific features of the cycle are: people from three emblematic communities and the cannibals as characters; an initial frame and their successive episodes; the trial; the gradation.

The analysis uncovers the hidden meaning of every specific feature, posing questions about their function. Why is it that the joke must include three successive episodes? The behaviour of the first two characters creates an expectation of a normal reaction of the third character, destroyed at the point of the joke. What is the function of the trial? The trial is a specific rite of passage, etc. These steps help to uncover the hidden meaning of the joke cycle: the "Our" (here - the Bulgarian) character succeeds in proving that he has the cultural competence to become a member of the cannibal society because we are uncivilised, aggressive, "cannibals"... The conclusion is that these jokes release masochistic impulses and they are aimed not at the "Others", but at "Us", or, this is a specific type of auto-racism.
\end{abstract}

Key words: auto-racism, cannibals, folklore, genre, humour, joke, jokelore

Arvo Krikmann (2006) has reviewed contemporary humour theories and classified them in 3 groups:

1. Theories of incongruity, or inconsistency, or contradiction, or bisociation.

2. Theories of superiority, disparagement, criticism, or hostility.

3. Theories of release, relief, or relaxation.

With all respect to Prof. Krikmann I would prefer to re-arrange his generalisation. Thus, the first category may be extended to a more general formulation - these are theories (logical and linguistic), which explain how laughter is produced and what kind of mechanism makes the joke possible. On the other hand, categories 2 and 3 can be integrated as theories regarding the social contribution of the joke. Thereby, we have two conclusions: 
1. Theories of the semiotic game (linguistic or logical) mechanism producing laughter.

2. Theories of cultural functions of laughter as a specific human reaction. This reformulation leads to an explicit research function that must follow simultaneously two directions. On the one hand, the joke-producing game mechanisms should be investigated, i.e. the humour instruments - these questions exist in the field of semiotics. On the other hand, the very human ability of laughing must be analysed; in this direction we should try to answer the questions "why are we laughing?" and "what makes us laugh?" - and these questions lie in the field of semantics. The goal of this operative function is to prove the fundamental interdependence between game mechanisms and the plot. For this purpose two methodological frames can be applied: the mature non-enigmatic structuralism, developed in Tartu and Paris (regarding questions of semiotics), and the reception theory, formulated in Constance, referring to the reception and the contribution of the work (on the question of semantics) ${ }^{1}$, from which the results will be expressed in psychological terms.

The chosen methodology requires a specific approach to the material, mainly regarding the choice of the joke cycle as a research project. Two reasons motivate this decision. Firstly, there is no strictly drawn border between the joke and the "neighbouring" texts. Thus, collections of jokes share a lot of non-joke forms (play upon words, puns, bon mots, inversed wellerisms, etc.). It is enough to take a pun, to put it in the frame of Radio Erevan was asked..., to place it in a situation of joke speech and we will have a joke, or, a quasi-joke. It is specific for the most part of undisputed jokes that they generate cycles - this is the second difference between schwank and joke, the first one being the point of the joke, as Arvo Krikmann (2009) argues.

Secondly, the joke cycle is the field where semiotic and semantic issues can be observed simultaneously. This is due to the fact that every joke cycle is focused on certain social phenomena and carries a constant message. On the other hand, many jokes from a cycle and, as a rule, have largely a common structure. So, we can conclude that to a not too inconsiderable degree each joke cycle is characterised by the unity of structure and message ${ }^{2}$. Actually, there are two types of joke cycles: subjective, i.e. focused on a concrete character (blondes, cops, Scotsmen, Stirlitz, etc.), and predicative, organised by a specific situation (Man caught the golden fish, Man returned home from a business trip, People caught on an island by cannibals). The last plot will occupy our attention in the following pages - following the outlined plan firstly, we will define the semiotic game, which organises the joke cycle (structure), then, we will reveal its cultural function (semantics). 


\section{STRUCTURE}

All variants of this joke cycle, which I found in the Bulgarian Internet, are included in the appendix to the paper. It is not impossible that some other examples can be added too, but they would scarcely change the picture. The narratives have a stable plot structure: after an accident (a plane or a shipwreck) three men of different communities (nationalities) find themselves on an island of cannibals. After the natives' hostile reception they get a chance to save their lives by passing a trial process. One of them reacts in an untypical way (far from our notions of normality), and usually saves his life. From a formal point of view the jokes of this cycle are composed of an initial frame and three successive episodes: two of them are quite similar, and the third one is completely different. This third episode is the point of the joke, or, the moment of the "narrative transformation" (Todorov 1980), i.e. this is the moment when the initial situation is transformed to the final scene. It is not a coincidence that characters are exactly three: the reactions of the first two men are necessary to create an expectation of a normal reaction by the third one (the "horizon of expectations"), which the outcome will virtually destroy.

Burlesque variants of this joke cycle also exist - then the different reaction of the third character does not save him (see examples Nos. 15-17). However, even in this case the point or the transformation is not omitted, so it is an example of zero transformation - "when the effort for change of the previous situation is ruined" (Todorov 1980: 130, see also Todorov 1978). Moreover, zero transformation is typical for the jokes because the stabilisation of a plot creates the opportunity for the emergence of its burlesque doubles, which provoke laughter on the basis of the "misleading expectations". A long time ago Henry Bergson (1924: 41) reminded us of two classical definitions of laughter: "Laughter could be a symptom of an effort which suddenly turns out useless" (Herbert Spencer) and "Laughter is the effect of a sudden transformation of a tense expectation of nothing" (Immanuel Kant) ${ }^{3}$.

The joke cycle Island of cannibals is a part of a bigger group of exaggeration jokes which can also be named gradational. The role of exaggeration as a source of humour is well-known - there is no need to look for many authoritative opinions; it is enough to once again quote Bergson: "Exaggeration is comic when it is continuous and mostly when it is systematic". This formulation needs to be supplemented: although it is used as constructive technique, the systematic exaggeration is not comic taken alone - to provoke laughter, even the strongest exaggeration must be expressed by a signal which is alien to the established logic, by opening of another plan. This opinion can be illustrated by the following political joke: 
The presidents of the great nations asked God:

Reagan: How many years will pass to the moment when my nation will become absolutely happy? - 50 years. Reagan left crying.

Mitterrand: The same question. - 100 years. Mitterrand left crying.

Gorbachev: The same question. - God left crying.

It is clear that, if in the point of the joke, some immense number (as 10000 ) was mentioned, the exaggeration would not be funny. This leads to the assumption that laughter is provoked not by the exaggeration itself but by the invasion of a signal which is alien to established expectations. Thus, the constructive mechanism acts in the following way: a gradation is set up which ends with a leap, foreign to the current logic of gradation. In other words, we have an opening of a second plan, which results in pushing of gradation logic beyond its natural border (from a formal point of view), or in exaggeration which cannot be exceeded (from a semantic point of view). Another example will illustrate this mechanism:

Three trappers were boasting while sitting by the fire. The first one said: "Once I was sleeping on my horse and when I woke up I saw a bison herd running against me. I took my gun, started shooting and killed 100 bisons to make a path among them!"

The second: "Once I entered an Indian village and the men of the tribe attacked me. I killed them all with my gun - there were over 200 warriors!"

Then the third trapper calmly stirred the coals with his penis.

It is obvious even from these few examples that a radical transformation occurs in the point of the joke: either the action is changing, or the statute, or the roles. If we go back to the cycle Island of cannibals, we shall see that the third character does not just do something more than the others; he does it in a totally different way. The turnover is manifested also by the change of the roles - the knowledgeable becomes unaware. Principally, the exaggeration jokes have a 3-episode structure, but this is not the rule - they can be reduced to the structure question - answer. In this case the notion of "normal" appears in the minds of the listeners in the time gap between the question and the answer, as in this joke:

How did the Grand Canyon appear? A Scotsman lost a penny in a ditch...

Nevertheless, all joke variants of the "cannibal" cycle contain the first two reactions, and it seems that they cannot be omitted. This fact is meaningful too $^{4}$, and on this basis a supplementary meaning can be extracted: the first two reactions are necessary to stabilise the image of the cannibals which is not 
altogether stereotypical - the cannibals are aggressive, but not uncultured and this, as we shall see, is meaningful. This is the next bridge between structure and semantics: the 3-episode structure is necessary for the shaping of the cannibals' image.

\section{SEMANTICS}

The plot of the "cannibal" joke cycle comprises a story of a competition between people from different nations (the gradation is a figure of the competition - this is the next link between structure and meaning), and the rules of the game are set by unprejudiced arbiters who are not influenced by nation's prestige. The competition winner is the "Our" character (here - the Bulgarian, or the Russian) who is more resourceful than the representatives of the great nations. Thus, the reception contribution of the cycle and the reason for its telling is that the narrator and his/her listeners enjoy, in a compensatory manner, the game situation where the "Our" character defeats those who usually outmatch "Us". This is the infantile delight in accepting a dream as reality. Indeed, some of the jokes do not contain any other reception contribution (as Nos. 1-4, which we define as narcissistic).

But this statement is nothing but a simplification and it does not reveal the potentials of others examples. If we carefully look at the images of representatives of different nations we shall find that the jokes do not give reason to conclude that the "Others" (the American, the Frenchman or the Englishman) are less flexible; they are just more cultured while the Bulgarian is obviously more primitive. Thus, the big difference between characters follows the dichotomy nature - culture. Moreover, the first two characters act rationally while the third one does so irrationally. Then isn't it the message of the joke: we are less cultured but this situation has some advantages?

This conclusion does not reveal all the meanings that the jokes contain. We must further provide an answer to some more questions: why such a long initial frame is necessary, why the jokes persistently return to the island of cannibals (next minus-device). According to the rules of speech economy, if the frame is not a part of the message, the jokes could begin with the utterance: An American, Frenchman and Bulgarian took a decision to compete under the following conditions... But in this case the joke will disappear. Why?

The island of cannibals is necessary to underline the competition's peculiarity - it is not a simple competition, but an initiation, a rite of passage, as it was defined by Arnold van Gennep (2004). It is well known that the initiation trials in archaic societies are rituals which permit the adolescent to become a 
full member of the community. From this point of view, the representatives of different nations cannot pass the trial - not because they do not possess personal abilities, but because they lack necessary cultural competences. In contrast, the "Our" character succeeds because he is familiar with the cannibal's cultural codes and norms, because he feels himself at home among them. Furthermore, he succeeds even to surprise the cannibals because the norms in his own country are even more cannibalistic that in the cannibals' society.

What does this mean? Though the "Our" character wins the competition, the jokes emphasise that the victory is not due to his personal skills but to the fact that he is living in a society, similar to the cannibals' one; the Bulgarian succeeds, because the Bulgarians are uncivilised, aggressive, cannibals... In these cases the jokes release masochistic impulses, which are aimed not at everyone else, but at us - because we find in ourselves the same features, which we hate in the "Others". This is the opposite side of national narcissism, which does have nothing in common with rational self-criticism: this is the reason to name these jokes masochistic.

From this analysis we can extract a more fundamental conclusion: the jokes with characters representative of different nations are compensatory - they are a cultural mechanism to redeem our low national spirit.

The compensation can be manifested in two ways: narcissistic (when without good reasons we consider ourselves identical with civilised nations); or masochistic (when, again without solid grounds, we assume that we are uncivilised). That is why through one character there can be expressed such contradictory messages at one and the same time that: we are and we are not civilised.

Yet, we have not extracted all messages that the analysed cycle contains. A joke with similar structure, but with a different frame, gives a hint for the discovery of another important element:

The devil caught the American, the Frenchman, and the Russian, and gave them two tests: to drink 10 bottles of alcohol and to sleep with 10 women.

The American confessed that he is able to drink 3 bottles and he is able to sleep with 3 women.

The Frenchman announced that he is able to drink 5 bottles and to sleep with 5 women.

The Russian declared that he will drink 11 bottles because he always has a bottle in his pocket. Then he suggested sleeping with 11 people, because the devil looked sexy too. 
In this case the cannibals are replaced by the devil but this does not confuse the message, which can be understood in two ways: narcissistic (the "Our" character transcends the devil's wile), or masochistic (the "Our" character is more amoral than the devil). Thus, the cannibals and the devil are counterparts and the choice between two initial frames is one between violations of two taboos: blasphemy and racism. This fact reveals another blind spot - the joke cycle Island of cannibals contains arrogant attitudes toward primitive and non-European cultures, and it is straightforwardly racist. In order to make sure that we are correct we should speculate on the question: why the initial frame is "men are caught on an island by cannibals", and not "men are caught by an aggressive cannibal tribe"? There are two possible answers: firstly, because the cycle is stabilised following the pattern of texts like "Robinson Crusoe"; secondly, because the image of the island is necessary to underline that the scenery is not in Europe, i.e., to produce the racist message.

But the racism of this joke cycle is unusual as it is not directed against the "Others" but against "Us"; this is auto-racism, because in "Us" we discover features that we hate in the "Others". This statement might look as an overinterpretation, but actually it is not: in Bulgaria, where the joke cycle is wellknown, the contextual background being idioms such as "we joined the African countries", "if only we could feel as the white people", "we are like Indians"; in Bulgaria the clichés "Bulgarian work" and "Gipsy work" are synonymous and have the meaning of 'incomplete, poorly done work'. It is clear - at least after the pioneer work of George Lakoff and Mark Johnson (1980) - that "the metaphors we live by" influenced our notions and even our everyday activities. The presence of the joke cycle in a concrete culture is a symptom, in which its bearers develop masochistic auto-racism, which, of course, gives the comfort of thinking of themselves as innocent victims.

A similar hypothesis has been presented in Bulgarian scientific research by Aleksandar Kyosev (1998: 9f.). He proposed the concept of self-colonisation to describe the policy of Bulgarian intellectuals after the liberation from Ottoman rule (1878), orientated towards the overcoming of the feeling of backwardness and on the creation of cultural standards, similar to European ones. He speculates that self-colonisation is a peculiar situation where a culture finds itself uncivilised because it sees itself from the perspective of civilised foreigners. This policy persisted in Bulgaria until World War I, after which the appeal "back to the roots" replaced the call for "Europeanisation". It is symptomatic that this line exactly coincides with the public attitude towards the Bulgarian joke character Bay Ganyu.

Its origin is literary - the name is borrowed from Aleko Konstantinov's book "Bay Ganyu" (1895), the first part of which consists of stories - funny and sad at 
the same time, - about the inadequate reactions of a Bulgarian during his trips in civilised Europe. So far there is nothing unexpected - a lot of joke characters are based on literary characters (Natasha Rostova and Lt. Rzhevskii, Stirlitz, etc.), and some of them become joke personifications of national characters (as Tartarin of Tarascon in France, Švejk in the Czech Republic). There is another interesting point - when Konstantinov's book was published the Bulgarians recognised Bay Ganyu as an anti-hero and were shocked at the idea that he could be thought as a personification of the Bulgarian national character. But during World War I the Bulgarians started to sympathise with Bay Ganyu and recognised him as a typical representative of the nation. Later the fluctuations of the attitude to him became more balanced and nowadays we are inclined to accept Bay Ganyu simultaneously with a sympathetic and ironic identification (Jauss 1978b: 150-153), i.e. we accept and reject him at one and the same time ${ }^{5}$.

Probably the evolution of the joke cycle Island of cannibals followed the same pattern. The masochistic jokes appeared first (otherwise, the initial frame would be unnecessary), and later as a replica - the narcissistic and burlesque variants. Nowadays they exist simultaneously, and depending on the context, we laugh in a compensatory way, giving vent to our narcissistic or masochistic impulses. As the structure poses the problem of negative and positive features of our national character, but does not resolve it so - the final judgment depends on stereotypes incorporated in the joke.

$$
* * *
$$

And eventually, two conclusions must be outlined. The first one is the successful decision to choose the cycle as the main element of analysis. If we have interpreted a single joke or the full thematic group of jokes about national character, we would miss determining that these jokes function as being political (when they are narrated in a totalitarian state) and the fact that, in their depth, they are racist.

The second conclusion is that the joke cycle is a narrative matrix, which enables the realisation of certain compensations whose type depends on stereotypes used in the joke. Thus, the joke cycle Island of cannibals poses the issue of the national character in the same way as the cycle Man caught a golden fish calls on the story of the missed chance - but this article has not been written yet. 


\section{APPENDIX}

\section{Narcissistic}
A. Characters
B. Trial
C. Result
D. Point

1 Englishman, To wash their The Englishman German, Bulgarian. socks, to sleep with a native woman and to write their autobiography in 5 minutes. washed his socks, the German wrote his autobiography, the Bulgarian succeeded in doing everything.

How did he do that? He made the woman stand on all four, penetrated her from the back, wrote his autobiography on her back, and made her wash his socks. "If we had tied a frame-saw to my ass, I would cut wood too!"

2 American, Frenchman, To make natives laugh and then Bulgarian. shock them with the totem animal of the tribe - a horse.

The cannibals will cut the penises of the victims depending on their professions.

4 American, Frenchman, Bulgarian.
To suggest an insoluble riddle.
The American and the Frenchman failed completely on the first stage. The Bulgarian succeeded in both.

"How did you manage it?" - "First I said to the horse that my penis is bigger than his and then I showed it to him".

The American woodcutter (with frame-saw), the Frenchman - butcher (with chopper).

The American: "100 penises - 1 rope?" -"100 men are pulling a ship". The Frenchman: "100 ropes - 1 penis?" "Parachutist". The riddles were solved.
The Bulgarian: "9 wings - 5 penises?" - "No idea". - "Ninewingy fivepenis". 


\section{Masochistic}
A. Characters
B. Trial
C. Result
D. Point

American, To have good

The American:

The Bulgarian:

Frenchman, recommenda-

"Let me go! I am a

Bulgarian. tions (hidden trial).

friend of Bill Clin-

ton!" The Frenchman: "I am a

"Such people did not impress you, how can I - an friend of General De Gaulle!" The cannibals were not impressed and ate them.

engineer from Sofia University?" - "When did you graduate?" "Which courses did you take?"

6 George Bush, To find the Bush and Putin Vladimir unique male failed, Petar StoyPutin, Petar Stoyanov. mosquito among millions of females.

succeeded.

How? "I entered and introduced myself: I am Petar Stoyanov, the president of Bulgaria!" And one of the mosquitos replied: "Fuck my cock"! ${ }^{6}$

7 American, Frenchman, To teach a dog (the totem animal) to speak. The cannibals gave food and instructed the victims to take care of the animals.

8 American, To make someFrenchman, thing unseen Bulgarian. with two small balls.

The American and the Frenchman did not succeed in making the dog speak.

The dog given to the Bulgarian was exhausted of starvation. "Did you feed the dog?" asked the chieftain. "Of course!" - "He is lying" - replied the dog.

The American juggled with them, the Frenchman did conjuring tricks, but the Indians were not impressed. The Bulgarian took the balls and ran, they caught him.

9 American, To say an unFrenchman, heard word Bulgarian.

The American: "Atomic bomb", the Frenchman: "French love" - the cannibals started a discussion: huggermugger and decided to put them in the boiler.
"He made something unseen: lost one of the balls and broke the other one".

The Bulgarian said: "Plenum". "What is plenum?" - "Just like your discussion: huggermugger and a man is put in the boiler". 
10 American, Frenchman, Bulgarian.

11 Frenchman, German, Russian.

12 American, Frenchman, Russian.

13 University students from: the Sofia University (mostly humanitarian), the Architectural and the Engineering Universities in Sofia.

14 American, Englishman, Bulgarian.
To say what is the biggest pleasure.

To hit a hawk with a rifle.
The Frenchman: "Women, wine, Moulin Rouge", the Englishman: "Golf, castle, RollRoyce". The cannibals were not convinced. The Bulgarian asked the chieftain to drink beer with him. After 10 beers the chieftain wanted to go to the toilet. "Hold on" - replied the Bulgarian.

The Frenchman and the German failed and requested one final drink as a last wish. In contrast, the Russian first requested some drinks, drank them, shot and hit.
To produce not less than 5 minutes echo.

The American: "O-key-ey-ey-ey!" - 2 minutes. The Frenchman: "Merci-i-i-i-i-i!" - 3 minutes.

To count how The first and the many sheep second failed. The there are in a third told the corhuge flock. rect number (e.g.: $4389524)$.
When the situation became unsupportable, they went to the toilet and started to urinate. The chieftain was convinced: "This is the biggest pleasure!"

"How did you succeed?" - "With ten guns it is not difficult to hit one of the twenty hawks!"

The Russian: "Vodka!" - "Whe-e-e-e-ee-ere?" -2 hours.

- "How did you do it?" - "It was easy! I counted their legs and divided into 4".

Get on the guillotine and survive if it fails to work.
The Bulgarian
was pushed to go first. The guillotine failed.
He said: "Give me a screwdriver and machine oil to repair this guillotine!" 


\section{Burlesque}
A. Characters
B. Trial
C. Result
D. Point

15 First, Second, Third.

16 First, Second, Third.

\section{First,} Second, Third.
Choice between "fucky-fucky" and "yummyyummy".

Choice between "fucky-fucky" and death.

To bring 10 pieces of a certain fruit, necessary for a second, unknown trial.
The first and the second chose "fucky-fucky". They were raped by the cannibals and then eaten. The third chose "yummyyummy".

The first and the second chose "fucky-fucky". They were raped by the cannibals and then eaten. The third chose the death.

The first brought 10 pieces of avocado, the second 10 blueberries. The second trial was to put them in their ass without a sound. The first failed, the second reached almost to the end and started to laugh.
OK! But first "fucky-fucky"!

OK! "Fucky-fucky to death"!

Why? Because he saw that the third is coming with watermelons. ${ }^{8}$

\section{NOTES}

1 From the theoretical school (Jauss 1978a) I have borrowed the term horizon of expectation and the policy of reconstructing the recipient's reaction.

2 This approach is also not typical for the Bulgarian scholarly tradition, represented by the books of Stanoy Stanoev (2005) and Ana Dimova (2006). The orientation towards joke cycles as an object of research seems to be a new tendency, see, for example, Stanoev 2010.

3 We must again mark the symmetry between structure and semantics: the zero transformation is connected with another source of laughter - the misled expectations. This change also influences the characters - they are no more representatives of different nations, but are simply the first, the second and the third. 
${ }^{4}$ Following Yuri Lotman's idea that the lack of a signal is a signal too - to describe it, the scholar has introduced the concept of the "minus-device" (Lotman 1998: 59-60).

5 The fluctuations in the attitudes to Bay Ganyu, the overuse of his image in arts and the shaping of his figure as a joke character are described and analysed by Inna Peleva (2002: 265-286).

6 Variant: George Bush, Vladimir Putin and Georgi Parvanov, i.e. American, Russian and Bulgarian.

7 Plenum - a session of the Central Committee of the Communist Party.

8 Another variant: each must choose a weapon (and then put it in his ass). The first comes with a tommy-gun and failed, the second - with a pistol and almost succeeded, but he laughed because he saw the third coming with a tank.

\section{REFERENCES}

Bergson, Henry 1924 (1900). Le rire. Essai sur la signification du comique. Paris: Éditions Alcan.

Dimova, Ana 2006. Vitsat kato ezikov i kulturen fenomen. Nemsko-balgarski paraleli. Prevodimost. Veliko Tarnovo: Faber.

Gennep, Arnold van 2004. Arnold Van Gennep. The Rites of Passage. London, Routledge, 2004.

Jauss, Hans Robert 1978a. L'histoire de la littérature: un defi à la théorie littéraire. In: Pour une esthétique de la réception. Paris: Gallimard, pp. 21-80.

Jauss, Hans Robert 1978b. Petite apologie de l'expérience esthétique. In: Pour une esthétique de la réception. Paris: Gallimard, pp. 123-157.

Krikmann, Arvo 2006. Contemporary Linguistic Theories of Humour. Folklore: Electronic Journal of Folklore. Vol. 33, pp. 27-58.

Krikmann, Arvo 2009. "Kontsovka" - mezhevoi stolb v istoricheskom razvitii zhanra folklornoi shutki? Ot shvanka ATU k sovremennomu anekdotu. www.ruthenia. ru/folklore/krikmann2.pdf, last accessed on 25 March 2012.

Kyosev, Aleksandar 1998. Spisatsi na otsastvashchoto. In: A. Kyosev. Balgarskiiat kanon? Krizata na literaturnoto nasledstvo. [Bulgarian Canon? The Crisis of Literary Heritage.] Sofia: NBU, pp. 5-49.

Lakoff, George \& Johnson, Mark 1980. Metaphors We Live By. Chicago: University of Chicago Press.

Lotman, Yuri 1998. Struktura khudozhestvennogo teksta. In: J. Lotman Ob iskusstve. St. Petersburg: Iskusstvo, pp. 14-285.

Peleva, Inna 2002. Aleko Konstantinov. Biografiia na cheteneto. Sofia: Prosveta.

Stanoev, Stanoy 2005. Vitsat i negovite poslaniia. [Jokes and Their Messages.] Sofia: Akademichno izdatelstvo "Marin Drinov".

Stanoev, Stanoy 2010. Dumb Blondes and Democracy. Folklore: Electronic Journal of Folklore, Vol. 46, pp. 43-60. 
Todorov, Tzvetan 1978. Les deux principes du récit. In: Les Genres Du Discours. Paris: Seuil, pp. 63-77.

Todorov, Tzvetan 1980. Poétique de la prose (choix) suivi de Nouvelles recherches sur le récit. Paris: Seuil. 